\title{
Soil and Water Pollution with Fluoride, Geochemistry, Food Safety Issues and Reclamation-A Review
}

\author{
Neelam Yadav ${ }^{1}$, Khushboo Rani' ${ }^{2}$, S.S. Yadav ${ }^{3 *}$ D.K. Yadav ${ }^{2}$, \\ V.K. Yadav ${ }^{4}$ and Nagesh Yadav ${ }^{3}$ \\ ${ }^{1}$ Institute of Agricultural Sciences, Banaras Hindu University, Varanasi, India \\ ${ }^{2}$ ICAR-Indian Agricultural Research Institute, New Delhi, India \\ ${ }^{3}$ S.K.N. University of Agricultural Sciences, Jobner, India \\ ${ }^{4}$ Rajasthan College of Agriculture, MPUAT, Udaipur, India \\ *Corresponding author
}

\begin{tabular}{|l|}
\hline Ke y w or d s \\
$\begin{array}{l}\text { Prosopis julifora, } \\
\text { Soil and water } \\
\text { pollution, } \\
\text { Geochemistry }\end{array}$ \\
\hline Article Info \\
\hline $\begin{array}{l}\text { Accepted: } \\
10 \text { April } 2018 \\
\text { Available Online: } \\
\text { 10 May } 2018\end{array}$ \\
\hline
\end{tabular}

\section{A B S T R A C T}

Fluoride $\left(F^{-}\right)$contamination in groundwater has been recognized as a serious problem worldwide. It is estimated that more than 200 million people from 25 countries are under the dreadful fate of fluorosis, among them India and China are the two worst affected countries In India 62 million people (including 6 million children), suffer from dental, skeletal or non-skeletal fluorosis because of consumption of fluoridecontaminated water. Rajasthan is one of the most affected states with fluoride concentration in the range of $0.1-14 \mathrm{mg} \mathrm{L}^{-1}$. The source of fluoride in soil and water is predominantly geogenic and released by weathering of fluoride containing minerals such as fluorite and fluorapatite, while anthropogenic sources include brick industry, aluminium smelters and use of phosphatic fertilisers. The geochemistry of fluoride is mainly governed by two processes i.e. enrichment and leaching. Fluoride mobility in soil is highly dependent on the soil's sorption capacity, which varies with $\mathrm{pH}$, salinity and types of sorbents present in soil. In general, fluorine present in soil as minerals, adsorbed on clay and oxy-hydroxides, while a few amount is present as dissolved form in soil solution. Fluoride normally enters the human body through water, food, industrial exposure, drugs, cosmetics etc. The fluoride levels of food depend upon the nature of soil and quality of water used for irrigation and thus varies from place to place. Prosopis julifora is a hyper-accumulator of $\mathrm{F}^{-}$and has potential to remediate fluoride contaminated soils (Baunthiyal and Sharma, 2012). Fluoride ion concentration in drinking water can be easily detected by ion selective electrode. Various defluoridation techniques have been developed to reduce the fluoride content to the desired level including principally membrane and adsorption processes (Amor et al., 2001). Different bio-sorbents such as chitosan coated silica (Krishnaiah et al., 2009) stalks of sorghum and canola are efficient in removal of fluoride from water. Apart from these technical approaches awareness among the people needs to be created for prevention from fluoride health hazards. 


\section{Introduction}

Over the past few decades, the ever-growing population, urbanization, industrialization, and unskilled utilization of resources have led to degradation of soil and water quality in different parts of the world. Due to various ecological factors either natural or anthropogenic, soil and water resources are getting polluted because of the disposal of hazardous wastes, liquid and soil wastes from industries, sewage disposal, surface impoundments, etc. In many cases, the water sources have been rendered unsafe not only for human consumption but also for other activities such as irrigation and industrial needs. In recent years the presence of fluoride in higher concentration in food and water has become a matter of global concern. It has been estimated that about 200 million people from 25 nations are under the dreadful fate of fluorosis (Ayoob and Gupta, 2006). The problem has aggravated more in developing countries like India and China where more than half of the population are dependent on groundwater to meet their daily requirements of drinking water, irrigation and other uses. Even though fluoride is considered as an essential element for human health, especially for the strengthening of tooth enamel, excessive doses can be harmful. While fluoride is present in air, water, and food, the most common way it enters the food chain is via drinking water (Fawell et al., 2006). According to the World Health Organization (WHO), at concentrations above $1.5 \mathrm{mg} / \mathrm{L}$, fluoride is considered as dangerous to human health. Excessive fluoride can lead to dental and skeletal fluorosis. Long term ingestion of fluoride rich drinking water may show the way to crippling bone deformities, cancer (Kowalski, 1999) decreased cognitive ability, lower Intelligence Quotient and developmental issues in children. The presence of fluoride in water does not impart any colour, odour or taste. Hence, it acts as an invisible poison such as arsenic in groundwater.

\section{Global and Indian scenario of fluoride}

Fluoride content in drinking water varies around the world depending on the geographical location. Fluoride contamination has been widely reported in groundwater in different parts of the world especially from the humid tropics. These areas include Africa, China, South Asia and Middle East (Ayoob and Gupta 2006). The two most populated nations in the world, China and India, stand the top in the list of worst hit nations with high fluoride groundwater.

\section{Geochemistry of fluoride}

\section{Sources of fluoride}

There are mainly two sources of fluoride in groundwater and soil.

a) geogenic and b) anthropogenic.

\section{Geogenic sources}

In nature, fluorine is widely found in sedimentary phosphate rock deposits and minerals (Kirk-Othmer, 1980). The main fluorine-containing minerals are fluorspar or fluorite, fluorapatite and cryolite. For industrial purposes, the most important source of fluorine is mineral calcium fluoride (fluorite or fluorspar, $\mathrm{CaF}_{2}$ ), which has a fluorine content of $49 \%$ (Fuge, 1988). Fluorite, commercially known as fluorspar, is usually associated with quartz, calcite, dolomite, or barite. Although the largest amount of fluoride exists as fluorapatite $\left[\mathrm{Ca}_{5}(\mathrm{OH}, \mathrm{F})\left(\mathrm{PO}_{4}\right)_{3}\right]$, this mineral is mined mainly for its low inorganic fluoride $(4 \%$ fluorine) (Kirk- Othmer 1980). By comparison, cryolite $\left(\mathrm{Na}_{3} \mathrm{AlF}_{6}\right)$ is rare $(54 \%$ of F). In addition to $\mathrm{CaF}_{2}$, fluorapatite, and 
cryolite, a number of other silicates, such as topaz $\left(\mathrm{Al}_{2} \mathrm{SiO}_{4}(\mathrm{OH}, \mathrm{F})_{2}\right)$, oxides, carbonates, sulfates, phosphates, sellaite $\left(\mathrm{MgF}_{2}\right)$, and sodium fluoride or villiaumite, contain minor amounts of inorganic fluoride (Fuge, 1988). Host minerals, such as mica (layer silicates), amphiboles (chain silicates), apatite, and tourmaline, and clays, such as montmorillonite, kaolinite, and bentonite, also contain inorganic fluoride (Reimann and Decaritat, 1998). Fluorine may occur in limestone that is associated with tremolite, actinolite, and pyroxene, where fluoride concentrations may reach a level of $0.4-1.2 \%$. A part of the fluorine may be present in clay material admixed with weathered limestone.

\section{Anthropogenic sources}

The sources of fluoride contamination is mostly geogenic in origin however in most developed and developing countries, the native soil fluoride content is strongly affected by various anthropogenic sources predominantly by the application of fertilizers and by deposition of industrial airborne pollutants. Fluoride content in the environment is being enriched by important emission sources which include burning of coal, steel production, chemical production, clay production, Al smelting, glass and enamel manufacturing, brick and ceramic manufacturing, application of fluoridecontaining fertilizers and pesticides, wastes from sewage and sludges, thermal power plants etc. Phosphatic fertilizers, especially the super-phosphates, are perhaps the single most important sources of fluoride contamination to agricultural lands. Rock phosphates generally contain approximately $3.5 \%$ of fluoride, phosphatic fertilizers contain between 1.5 and $3.0 \%$ fluoride (McLaughlin et al., 1996). Labile and water-soluble fluoride concentrations appear to be most affected by industrial pollution (Haidouti, 1991). Areas in the vicinity of phospatic fertilizers industry varied from $90 \mathrm{mg} \mathrm{kg}^{-1}$ to $23,700 \mathrm{mg} \mathrm{kg}^{-1}$ (average $8,940 \mathrm{mg} \mathrm{kg}^{-1}$ ). The highest values of $\mathrm{F}$ were found close to the factory. Further from the factory, the concentration of $F$ gradually decreased. The surface soil in the vicinity of brick field industries found to contain water-soluble fluoride (1:1) ranged from 0.59 to $2.74 \mathrm{mg} \mathrm{kg}^{-1} \mathrm{CaCl}_{2}$ extractable fluoride ranged from 0.69 to $3.18 \mathrm{mg} \mathrm{kg}^{-1}$, whereas the mean total fluoride concentration varied from 322 to $456 \mu \mathrm{g} \mathrm{g}^{-1}$ (Jha et al., 2009).

\section{Fluoride cycle in environment}

Fluoride is released in the atmosphere through volcanic eruptions, industrial emissions and other sources and is present in the atmosphere as aerosols. These aerosols combine with the precipitation and deposits on the surface of earth. Fluoride containing fertilizers and pesticides when applied to soil increases the concentration of fluoride in soil which gradually leaches down and contaminates the groundwater. Groundwater is also enriched with fluoride due to the weathering of the fluoride containing minerals in soil. Fluoride contaminated groundwater is used both for irrigation as well as drinking purpose and it ultimately enters the food chain causing various health hazards (Vithanage and Bhattacharya, 2015).

\section{Fluoride in soil}

The fluorine content of most rocks ranges from 100 to $1,300 \mathrm{mg} / \mathrm{kg}$ soil concentrations typically vary between 20 and $500 \mathrm{mg} / \mathrm{kg}$. However, much higher concentrations $(1,000$ $\mathrm{g} / \mathrm{kg}$ ) can occur in soils that are derived from rocks with high fluorine contents or in soils affected by anthropogenic inputs, such as phosphate fertilizers. In general, fluorine found in soils occurs within minerals or is adsorbed to clays and oxy-hydroxides, with only a few percent or less dissolved in the soil 
solution (Cronin et al., 2000; Pickering 1985). Fluoride is not readily released from soil because of strong association of fluoride with the soil components (Ayoob and Gupta (2006). The chemical speciation, soil chemistry and climate are the factors influencing the fluoride release from soils. The various factors governing the mobility of fluoride in soils are:

Soil pH

Exchangeable sodium percentage

Type of clay

Presence of $\mathrm{CaCO}_{3}$

In natural soil solution, the fluoride concentrations are normally a small proportion of labile soil fluoride and normally are $<1 \mu \mathrm{g}$ $\mathrm{mL}^{-1}$. In almost all soils, fluoride is strongly bound, and only in coarse clay and Fe/Al oxide-poor soils is the fluoride weakly held (Pickering, 1985).

Many common fluoride compounds are only sparingly soluble, e.g., $\mathrm{CaF}_{2}(0.016 \mathrm{~g} / \mathrm{L})$, $\mathrm{MgF}_{2}(0.13 \mathrm{~g} / \mathrm{L})$, and $\mathrm{Na}_{3} \mathrm{AlF}_{6}(0.42 \mathrm{~g} / \mathrm{L})$, although some others are quite soluble, e.g., HF, SiF4 (hydrates), and NaF (40 g/L) (Pickering, 1985). It has been observed that the solubility of fluoride in soils is highly variable and has the tendency to be higher at $\mathrm{pH}$ below 5 and above 6 . The solubility of fluoride tends to be lowest in the $\mathrm{pH}$ range of 5-6.5, which coincides with the greatest fluoride sorption (Wenzel and Blum, 1992). At lower $\mathrm{pH}$ levels, sorption decreases due to the formation of soluble $\mathrm{Al}-\mathrm{F}$ species such as $(\mathrm{AlF})^{2+}$ and $\left(\mathrm{AlF}_{2}\right)^{+}$complexes (Wenzel and Blum 1992).. At high $\mathrm{pH}$, there is development of $\mathrm{pH}$ dependent negative charges on the variably charged clay surfaces i.e, oxides and hydroxides of $\mathrm{Fe}$ and $\mathrm{Al}$. An increasingly unfavourable electrostatic potential decreases the retention of the fluoride ion to soil and increases the $F$ concentration in soil solution.
The increase of fluoride in the soil solution may also result from displacement of adsorbed fluoride, i.e., by the increased concentration of $\mathrm{OH}-$ in soil solution at higher $\mathrm{pHs}$ (Larsen and Widdowson, 1971) and by the isomorphous substitution of $\mathrm{OH}$ - ions from the clay minerals. The order in the ability of various materials to absorb $\mathrm{F}$ was as follows: $\mathrm{Al}(\mathrm{OH})_{3}$ precipitate on bentonite $\mathrm{Al}(\mathrm{OH})_{3} \gg$ hydrated hallosite and dehydrated halloysite $>$ a weakly acidic soil >> kaolinite > gibbsite > alkaline soil > goethite $>$ bentonite and vermiculite. $\mathrm{Al}(\mathrm{OH})_{3}$ has an extremely high $\mathrm{F}$ adsorption capacity. The $\mathrm{F}$ adsorption occurs primarily by exchange with $\mathrm{OH}$ groups from $\mathrm{Al}(\mathrm{OH})_{3}$, and basic $\mathrm{Al}$ polymers adsorbed on mineral surfaces, rather than by exchange with crystal lattice $\mathrm{OH}$ group of clay minerals. In calcareous soils, the formation of slightly soluble $\mathrm{CaF}_{2}$ and $\mathrm{F}$ complexes with $\mathrm{Al}, \mathrm{Fe}$, and $\mathrm{Si}$ is responsible for the low migration of this element. In sodic soils, on the other hand, high levels of exchangeable $\mathrm{Na}$ effects increased solubility of F. (Chhabra et al., 1980) had also reported a linear increase of water-soluble fluoride with the increase of exchangeable sodium percentage (ESP) (Chhabra et al., 1980 and Omueti and Jones, 1977).

\section{Fluoride in ground water}

Water is an essential natural resource for sustaining life and is among nature's most valuable gifts. It was earlier viewed as an infinite resource, but today, it is often considered as a limiting factor of human, social, and economic development for a region. The main source of freshwater for sustaining life on earth is groundwater. In India, about $80 \%$ of domestic freshwater needs in rural areas and $50 \%$ in urban areas are met by groundwater. Unfortunately, groundwater is either being increasingly depleted for irrigation of crops, industrial, or other uses, or is becoming contaminated by 
various pollutants. The individuals who rely on tube wells for freshwater are under threat from continuing exposure to excess fluoride, arsenic, iron, nitrate, and salinity The presence of fluoride as a contaminant of groundwater has become a worldwide problem, because it is commonly found in groundwater sources. The problem of high fluoride content in groundwater resources is important, because of both toxicological and geo environmental concerns. The level of natural fluoride that occur in groundwater ranges from 0.5 to 48 ppm, or more (Susheela, 2003).

Most of the fluoride in groundwater is naturally present due to weathering of rocks rich in fluoride. Water with high concentration of fluoride is mostly found in sediments of marine origin and at the foot of mountainous areas (Fawell et al., 2006). The extent of fluoride contamination in groundwater is influenced by the nature of local and regional geology and the existence of certain hydrogeochemical conditions. The chief source of fluoride in groundwater is fluoride-bearing minerals that exist in rocks and soils. The weathering and aqueous leaching processes that occur in soils play an important role in determining the amounts of fluoride that reaches groundwater. The various factors that govern the release of fluoride into water from fluoride-bearing minerals are:

The chemical composition of the water,

The presence and accessibility of fluoride minerals to water, and

The contact time between the source mineral and water (Keller, 1979).

In groundwater, the natural concentration of fluoride highly depends on the geologic, chemical, and physical characteristics of the aquifers. Overall water quality (e.g., pH, hardness, and ionic strength) also plays an important role by influencing mineral solubility, complexation and sorption/exchange reactions (Apambire et al., 1997). Fluoride minerals such as fluorite and cryolite are not readily soluble in water under normal pressure and temperature. But under alkaline conditions and range of specific conductivity between 750 and $1750 \mu \mathrm{S} / \mathrm{cm}$, dissolution rate of fluorite minerals increase (Saxena and Ahmed, 2001). Alkalinity mobilizes fluoride from fluorite with precipitation of calcium carbonate, because the solubility of $\mathrm{CaF}_{2}$ increases with an increase in $\mathrm{NaHCO}_{3}$ (Saxena and Ahmed, 2001).

$\mathrm{CaF}_{2}+2 \mathrm{NaHCO}_{3}=\mathrm{CaCO}_{3}+2 \mathrm{Na}++2 \mathrm{~F}-+$ $\mathrm{H}_{2} \mathrm{O}+\mathrm{CO}_{2}$

The occurrence of groundwater with high $\mathrm{HCO}_{3}{ }^{-}$and $\mathrm{Na}^{+}$contents and high $\mathrm{pH}$ value under the control of above water-rock interactions is the important reason for fluoride release from the aquifer matrix into groundwater (Guo et al., 2007). The above equation clearly shows the processes that could control negative (between fluoride and calcium) and positive relationships (between fluoride and bicarbonate) when both are in contact with each other. Water samples in which fluoride levels exceed $5 \mathrm{mg} / \mathrm{L}$ are oversaturated with regard to fluorite. Once fluorite reaches equilibrium, calcite is removed by precipitation, which allows the fluoride concentration to increase (Kim and Young Jeong, 2005). Moreover groundwater with high $\mathrm{HCO}_{3}$ - and $\mathrm{Na}^{+}$content are usually alkaline and have relatively higher $\mathrm{OH}$ content, so the $\mathrm{OH}$ - can replace the exchangeable F- of fluoride bearing minerals, increasing the F-content in groundwater. The reactions are basically as follows:

Muscovite:

$\mathrm{KAl}_{2}\left(\mathrm{AlSi}_{3} \mathrm{O}_{10}\right) \mathrm{F}_{2}+2 \mathrm{OH}=\mathrm{KAl}_{2}\left(\mathrm{AlSi}_{3} \mathrm{O}_{10}\right)$ $\mathrm{OH}_{2}+2 \mathrm{~F}^{-}$ 
Biotite:

$\mathrm{KMg}_{2}\left(\mathrm{AlSi}_{3} \mathrm{O}_{10} \mathrm{~F}_{2}+2 \mathrm{OH}=\mathrm{KMg}_{2}\left(\mathrm{AlSi}_{3} \mathrm{O}_{10}\right)\right.$ $\mathrm{OH}_{2}+2 \mathrm{~F}^{-}$

Longer residence time in aquifers with fractured fluoride rich rocks enhance fluoride levels in the groundwater. In natural water, the fluoride forms strong complexes with $\mathrm{Al}$, and therefore, fluorine chemistry is largely regulated by $\mathrm{Al}$ concentration and $\mathrm{pH}$ level (Skjelkvale, 1994). Below pH 5, fluoride is almost entirely complexed with Al, predominantly with the $\mathrm{AlF}_{2}{ }^{+}$complex, and consequently the concentration of free fluoride is reduced to low levels. As the $\mathrm{pH}$ increases, the $\mathrm{Al}-\mathrm{OH}$ complexes dominate over the $\mathrm{Al}-\mathrm{F}$ complexes, and the free fluoride level increases. Fluoride occurs at some level in almost all groundwater, but the concentration found in most potable waters is less than 1 $\mathrm{mg} / \mathrm{L}$ (Hem, 1985). It has been postulated that fluoride-bearing minerals are normally only sparingly water soluble, with the exception of villiaumite and these minerals release fluoride to water slowly (Saxena and Ahmed, 2003). The maximum concentration of fluoride in groundwater is usually controlled by the solubility of fluorite (Chae et al., 2007). Once the solubility limit for fluorite $\left(\mathrm{CaF}_{2}\right)$ is reached, an inverse relationship will exist between fluoride and calcium concentrations (Jha et al., 2011).

Earlier studies have revealed that there is a close association between high fluoride content and soft, alkaline (i.e., sodium bicarbonate) groundwater that is depleted of calcium (Chae et al., 2007). Igneous rocks that have been formed from highly evolved magmas are a rich source of fluorine bearing minerals. The plagioclase composition of igneous rocks is typically high in albite (Hyndman, 1985). As a result, the groundwater in contact with these rocks is often soft and calcium deficient, which allows for higher fluoride concentrations when equilibrium with fluorite. It has been found in past research that a direct relationship exists between $\mathrm{pH}$ levels and fluoride concentrations. In some cases, the influence of residence time produces a direct relationship between fluoride concentrations and the depth at which a water sample was collected (Chae et al., 2007). The influence of climate on fluoride concentrations in groundwater is largely attributed to rainfall, and to recharge rates and groundwater flow (Edmunds and Smedley, 2005). Areas of high rainfall, such as humid tropical regions, are less likely to have high fluoride concentrations in groundwater, because soluble ions such as fluoride are leached out and diluted. Conversely, some arid environments are noted for having high fluoride content, because the low rates of groundwater recharge lead to prolonged water-mineral interaction and higher salinities; such recharge enhances mineral dissolution (Handa, 1975). Climate can also influence dissolved fluoride levels. Temperature has a direct effect on the solubility of fluorine-bearing minerals. For example, the equilibrium constant for fluorite increases from $10-10.80$ at $10^{\circ} \mathrm{C}$ to $10-10.57$ at $25^{\circ} \mathrm{C}$ (Edmunds and Smedley, 2005), which allows for roughly $30 \%$ more fluoride to dissolve in dilute solutions

As given by the World Health Organization (WHO, 2004), the maximum limits of fluoride in drinking water should be $1.5 \mathrm{mg} / \mathrm{L}$. In hot tropical areas of the world, people consume more water and consequently. The risk of fluoride accumulation increases. People who inhabit tropical or semi-arid countries that lie between latitudes $10^{\circ}$ and $30^{\circ}$ north and south of the equator suffer extensively from endemic fluorosis (WHO 1992). The inhabitants of the majority of these countries that live in such zones are malnourished and are poor. WHO (2004) guidelines suggest that in areas with a warmer climate the optimal fluoride 
concentration in drinking water should remain below $1 \mathrm{mg} / \mathrm{L}$.

\section{Fluoride estimation in soil and water}

Water supply samples are frequently tested by municipal authorities. Numerous methodologies have been applied to the measurement of fluoride in various sample matrices. It is required to develop methods that can detect fluoride anions in aqueous solution. These include potentiometry with fluoride ion selective electrodes (Perdikaki, 2002), atomic absorption spectrometry (Gutsche, 1975), inductively coupled plasma emission spectrometry (Gehlhausen, 1989), UV-Vis spectrophotometry (Leon, 1989), chromatography (Jones, 1992) etc. The most commonly used method is fluoride selective electrode.

\section{Fluoride in food}

The fluoride of food items depends upon the fluoride contents of the soil and water used for irrigation, and therefore the fluoride content of the food items may vary from place to place. Virtually all foodstuffs contain at least traces of fluorine. All vegetation contains some fluoride, which is absorbed from soil and water. The highest levels in field-grown vegetables are found in curly kale (up to 40 $\mathrm{mg} / \mathrm{kg}$ fresh weight). Other foods containing high levels include fish $(0.1-30 \mathrm{mg} / \mathrm{kg})$ and tea. High concentrations in tea can be caused by high natural concentrations in tea plants or by the use of additives during growth or fermentation. Levels in dry tea can be 3-300 $\mathrm{mg} / \mathrm{kg}$ (average $100 \mathrm{mg} / \mathrm{kg}$ ), so two to three cups of tea contain approximately $0.4-0.8 \mathrm{mg}$ of fluoride. In areas where water with high fluoride content is used to prepare tea, the intake via tea can be several times greater (Fawell, 2006). Fluorine content of plants, mostly cultivated plants, is generally low, except for tea which contains high amount of fluoride. Fluoride content in vegetables (especially leafy vegetables) and other food crops have been reported to increase with increasing fluoride contamination of soil and irrigation water (Bhardwaj, 2010 and Ghosh et al., 2012 and Mohapatra, 2007).

\section{Effect of fluoride on human health}

\section{Metabolism of fluoride}

(i) Ingested fluoride is rapidly absorbed through gastrointestinal tract and lungs. The peaks are reached after $30 \mathrm{~min}$ in the blood (ii) The rapid excretion takes place through the renal system over a period of 4-6 h. About 50 $\%$ of the total absorbed amount is excreted in children less than 3 years of age, but about 90 $\%$ is excreted in adults and children over 3 years (iii) Generally $90 \%$ of the fluoride retained in the body is deposited in the skeleton and teeth (iv) The biological half-life of bound fluoride is several years (v) Fluoride also passes through the placenta and appears in low concentrations in saliva, sweat, and milk (Mahapatra, 2007 and Dissanayake, 1991) (Table 1)

\section{Dental fluorosis}

Tooth enamel is principally made up of hydroxyapatite $(87 \%)$ which is crystalline calcium phosphate. Fluoride which is more stable than hydroxyapatite displaces the hydroxide ions from hydroxyapatite to form fluoroapatite. On prolonged continuation of this process the teeth become hard and brittle. This is called dental fluorosis. Dental fluorosis in the initial stages results in the tooth becoming coloured from yellow to brown to black. Depending upon the severity, it may be only discolouration of the teeth or formation of pits in the teeth. The colouration on the teeth may be in the form of spots or as streaks usually these streaks on the teeth are horizontal. Children who are exposed to 
excess fluoride from childhood show symptoms of fluorosis very often than compared to adults. Hence the fluoride problem in an area may not be decided on the fact that the adults have good teeth with no symptoms of discolouration. Though the main source for dental fluorosis is fluoride ingestion through drinking water, it can also be ingested through toothpastes containing fluoride. It is common for children to swallow toothpastes which has to be avoided to prevent fluorosis

\section{Skeletal fluorosis}

Exposure to very high fluoride over a prolonged period of time results in acute to chronic skeletal fluorosis. India and China has been largely affected by crippling skeletal fluorosis with 2.7 million people being affected in China. Apart from ingestion of fluoride through drinking water, skeletal fluorosis also may be caused due to indoor use of coal as fuel and by air borne fluoride. Ingestion of fluoride through inhalation in factories and industries is one of the occupational health problems. Skeletal fluorosis does not only affect humans but also animals fed with fluoride rich water and fodder. Fluorosis is also now associated with heavy consumption of tea (Joshi et al., 2010). Early stages of skeletal fluorosis start with pain in bones and joints, muscle weakness, sporadic pain, stiffness of joints and chronic fatigue. During later stages, calcification of the bones takes place, osteoporosis in long bones, and symptoms of osteosclerosis where the bones become denser and develop abnormal crystalline structure. In the advanced stage the bones and joints become completely weak and moving them is difficult. The vertebrae in the spine fuse together and the patient is left crippled which is the final stage. Skeletal fluorosis is usually not recognized until the disease reaches an advanced stage.

Table.1 The fluoride concentration in the groundwater found in some major countries

\begin{tabular}{|c|c|c|}
\hline Country & Source & Fluoride conc. $\left(\mathrm{mg} \mathrm{L}^{-1}\right)$ \\
\hline Algeria & Fluorinated minerals & 0.4 to 2.3 \\
\hline Australia & Atmospheric & Up to 0.691 \\
\hline Brazil & $\begin{array}{l}\text { Phosphate fertilizer production } \\
\text { emission }\end{array}$ & 0.1 to 4.791 \\
\hline Canada & Fluoride rich rock & Up to15.1 \\
\hline China & $\begin{array}{l}\begin{array}{l}\text { Fluorine } \\
\text { androcks }\end{array}\end{array}$ & 2.5 to 10.3 \\
\hline Estonia & $\begin{array}{l}\text { Silurian-Ordovician } \\
\text { carbonaceous aquifer }\end{array}$ & 0.01 to 7.2 \\
\hline Ethiopia & Geochemical characteristics & 0.01 to 13 \\
\hline Ghana & $\begin{array}{l}\text { Fluorine enriched Bongo } \\
\text { coarse grained hornblende } \\
\text { granite and syenite suite }\end{array}$ & 0.11 to 4.60 \\
\hline Iran & $\begin{array}{l}\text { Dolomite and limestone along } \\
\text { with gypsum }\end{array}$ & 0.7 to 6.6 \\
\hline Jordan & Fluorite and calcite solubility & 0.009 to 0.055 \\
\hline Kenya & $\begin{array}{l}\text { Volcanic activity and chemical } \\
\text { weathering }\end{array}$ & 0.1 to 25 \\
\hline
\end{tabular}

(Brindha and Elango, 2011, Mohapatra, 2007 and Brindha and Elango, 2011) 
Table.2 Chemical compostion of various fluoride containing minerals

\begin{tabular}{|c|c|c|}
\hline Minerals & Chemical Composition & Rocks of these minerals \\
\hline $\begin{array}{l}\text { Fluorite } \\
\text { (Fluorspar) }\end{array}$ & $\mathrm{CaF}_{2}$ & $\begin{array}{l}\text { Pegmatite Pneumatolitic } \\
\text { deposits as vein deposit }\end{array}$ \\
\hline $\begin{array}{l}\text { Fluorapatite } \\
\text { (Apatite) }\end{array}$ & $\mathrm{Ca}_{5}(\mathrm{~F}, \mathrm{Cl}) \mathrm{PO}_{4}$ & $\begin{array}{l}\text { Pegmatite and metamorphosed } \\
\text { limestone. }\end{array}$ \\
\hline \begin{tabular}{ll}
\multicolumn{2}{l}{ Micas } \\
a. $\quad$ Biotite \\
b. $\quad$ Muscovite \\
\end{tabular} & $\begin{array}{l}\mathrm{K}\left(\mathrm{MgFe}^{+2}\right)_{3}\left(\mathrm{AlSi}_{3}\right) \mathrm{O}_{10}(\mathrm{OH}, \mathrm{F})_{2} \\
\mathrm{KAl}_{2}\left(\mathrm{AlSi}_{3} \mathrm{O}_{10}\right)(\mathrm{OH}, \mathrm{F})_{2}\end{array}$ & $\begin{array}{l}\text { Basalts } \\
\text { Permatites, Amphiboites, }\end{array}$ \\
\hline $\begin{array}{l}\text { Amphiboles } \\
\text { a. Hornblende } \\
\text { b.Tremolite } \\
\text { Actinolite } \\
\end{array}$ & $\begin{array}{l}\mathrm{NaCa}_{2}\left(\mathrm{MgFe}_{+2}\right)_{4}\left(\mathrm{AlFe}_{+3}\right)(\mathrm{SiAl})_{8} \mathrm{O}_{2} \\
2(\mathrm{OH}, \mathrm{F})_{2} \\
\mathrm{Ca}_{2}\left(\mathrm{MgFe}^{+2}\right)_{5}\left(\mathrm{Si}_{8} \mathrm{O}_{22}\right)(\mathrm{OH}, \mathrm{F})_{2}\end{array}$ & $\begin{array}{l}\text { Gneisses, schists, shales, } \\
\text { Clay, Alkaline rocks etc. }\end{array}$ \\
\hline Topaz & $\mathrm{Al}_{2} \mathrm{SiO}_{4}(\mathrm{OH}, \mathrm{F})_{2}$ & $\begin{array}{l}\text { Acid Igneous rocks, Schists, } \\
\text { gneisses etc. }\end{array}$ \\
\hline Rock Phosphate & $\begin{array}{l}\mathrm{NaCa}_{2}\left(\mathrm{Mg}, \mathrm{Fe}^{+2}\right)_{4}\left(\mathrm{Al}, \mathrm{Fe}^{+3}\right)(\mathrm{Si}, \mathrm{Al})_{8} \\
\mathrm{O}_{2} 2(\mathrm{OH}, \mathrm{F})_{2}\end{array}$ & Limestone, Fossils etc. \\
\hline
\end{tabular}

Table.3 Fluoride concentrations in various rocks

\begin{tabular}{l|l|} 
Rocks \\
Basalt \\
\hline Granites and gneisses \\
\hline Shales and clay \\
\hline Limestones \\
\hline Sandstone \\
\hline Coals(ash) \\
\hline Phosphorite
\end{tabular}

\begin{tabular}{|l|l|}
\hline Fluoride range $\left(\mathrm{mg} \mathrm{kg}^{-1}\right)$ & Average $\left(\mathrm{mg} \mathrm{kg}^{-1}\right)$ \\
\hline $20-1060$ & 360 \\
\hline $20-2700$ & 870 \\
\hline $10-7600$ & 800 \\
\hline $0-1200$ & 220 \\
\hline $10-880$ & 180 \\
\hline $24000-41500$ & 31000 \\
\hline $40-480$ & 80 \\
\hline
\end{tabular}

(Keller, 1979)

Table.4 Effect of temperature and calcium on fluoride solubility

\begin{tabular}{|l|l|l|}
\hline $\begin{array}{l}\text { Calcium conc. } \\
\left(\mathbf{m g ~ L} \mathbf{~}^{-1}\right)\end{array}$ & $\begin{array}{l}\text { Fluoride concentration at equilibrium with fluorite }\left(\mathbf{m g ~ L}^{\mathbf{- 1}}\right) \\
\text { At } \mathbf{1 0}{ }^{\mathbf{0}} \mathbf{C}\end{array}$ \\
\hline $\mathbf{4}$ & 7.56 & 9.86 \\
\hline $\mathbf{8}$ & 5.35 & 6.97 \\
\hline $\mathbf{1 6}$ & 3.78 & 4.93 \\
\hline $\mathbf{3 2}$ & 2.67 & 3.49 \\
\hline $\mathbf{6 4}$ & 1.89 & 2.46 \\
\hline $\mathbf{1 2 8}$ & 1.34 & 1.74 \\
\hline $\mathbf{2 5 6}$ & 0.95 & 1.23 \\
\hline
\end{tabular}

(Edmunds and Smedley, 2005) 


\section{Non-skeletal fluorosis}

This kind of fluorosis is often overlooked because of the wrong prevailing notion that fluoride affects only bone and teeth. Nonskeletal fluorosis can lead to gastrointestinal problems and neurological disorders. The preskeletal stage of fluoride intoxication poses problems for diagnosis. Moreover, the symptoms that are manifested are so varied that they may be identified with those of various other diseases. The complaints of the victims in such cases are so commonplace that they may be easily mistaken for those resulting from other ailments; for example, muscle/neurological involvement in children may be mistaken for Poliomyelitis.

Neurological manifestations. Muscular manifestations Allergic manifestations Gastro-intestinal Problems Urinary tract manifestations Headache

\section{Neurological manifestations}

Nervousness and Depression

Tingling sensation in fingers and toes

Excessive thirst and tendency to urinate frequently

Control by brain appears to be adversely affected

\section{Muscular manifestations}

Muscle Weakness and stiffness

Pain in the muscles and loss of muscle power

\section{Allergic manifestations}

Very painful skin rashes, which are perivascular inflammation. Prevalent in women and children.
Pinkish red or bluish red spots, round or oval in shape, appear on the skin that fade and clear up within 7-10 days.

\section{Gastro - intestinal problems}

Acute abdominal pain

Diarrohea

Constipation

Blood in Stool

\section{Effect of fluoride in plants}

Fluoride contaminated water when used for irrigation can result in toxicity symptoms on sensitive plants. In general, soil fluoride is not available to plants. Roots take up small amounts of soil fluoride diffusion, which results in a low background concentration in the plant foliage. There are exceptions such as tea plants that are natural accumulators of fluoride (Ruan, 2003). Gaseous uptake of fluoride by leaves is rapid due to its high solubility. Fluoride is an accumulative poison in plant foliage. Accumulation may be gradual over time. Fluoride strongly inhibits photosynthesis and other processes. It will move in the transpiration stream from roots or through stomata and accumulate in leaf margins. Typical fluorine injury symptoms on broadleaf plants include marginal and tip necrosis that spread inward. Conifer needles exhibit tip necrosis that spreads to the base. Drought stress or salt toxicity can have similar symptoms. A wide variety of plants are sensitive to fluoride toxicity. Typical indoor foliage plainclude Dracaena, Tahitian Bridal Veil (Gibasis pellucida), and the spider plant (Chlorophytcomosum). Both Dracaena deremensis and $D$. fragrans (corn plant) are very sensitive to fluoride toxicity. Fruits such as apricot, blueberry, grape, peach, and plums are also sensitive conifers that are sensitive include Douglas- fir, western larch, most pines, and blue spruce. Sensitive e flowering plants include gladiolus, lily, tulip, and yucca. 
Few reports are there on toxicity of $\mathrm{F}^{-}$in plants like urdbean and onion (Jha et al., 2009).

Avoiding fluorine toxicity starts with knowing which plants are sensitive. Avoid fluoridated water, high phosphate fertilizers, and low soil $\mathrm{pH}$. An exception would be low $\mathrm{pH}$ - loving plant like blueberry. High calcium levels in the soil or rooting medium, such as use of dolomite, can help tie up fluoride and prevent injury.

\section{Concentrations in plants}

Fluorine contents of plants have been investigated for a number of reasons such as assessing its hazard to grazing animals, the diagnosis of plant injury, and for monitoring airborne $\mathrm{F}$ pollutants. Higher concentrations of $\mathrm{F}$ have usually been reported for the aerial parts of plants. Mean F contents of plants grown in uncontaminated areas are very unlikely to exceed $5 \mathrm{mg} / \mathrm{kg}$. However, in some vegetables, for example, spinach leaves, its concentration may reach up to $24 \mathrm{mg} / \mathrm{kg}$ (Bhardwaj, 2012). According to general opinion, plant $\mathrm{F}$ seems to be positively correlated with the concentration of $F$ in rainwater. Several plants, especially forage vegetation, when growing in polluted areas are reported to contain large amounts of $\mathrm{F}$. Most of the $\mathrm{F}$ pollution is likely to be deposited on the leaf surface, which was shown by findings of Fuge and Andrews (1988). They reported that $\mathrm{F}$ in unwashed grasses from an area of china clay industry ranges from 756 to $3240 \mathrm{mg} / \mathrm{kg}$, whereas $\mathrm{F}$ ranged from 330 to $1410 \mathrm{mg} / \mathrm{kg}$ in grasses from the same area, but washed in distilled water. Results of the pot experiment clearly indicate that soil F is not an important source of this element to red maple and orchard grass. Pine needles are common and good indicators for the $\mathrm{F}$ pollution. Pine needles from the vicinity of an aluminium smelter contain $\mathrm{F}$ above $1000 \mathrm{mg} / \mathrm{kg}$, while the background value for $\mathrm{F}$ in pine needles in Poland is below $20 \mathrm{mg} / \mathrm{kg}$. Geebelen et al., (2005) used transplanted lichens as bio monitors for atmospheric $\mathrm{F}$ pollution and observed the $\mathrm{F}$ accumulation up to $243 \mathrm{mg} / \mathrm{kg}$ near the F point source (Gupta and Bannerjee, 2011).

\section{Mitigation measures}

Everybody needs clean water. When high fluoride in the drinking water source has been identified, it is better to avoid that source and look for other sources. But this is not a long lasting solution. In-situ and ex-situ methods are available to treat groundwater with high fluoride and bring it to the usable form.

\section{In-situ-treatment methods}

In situ method aims at directly diluting the concentration of fluoride (in groundwater) in the aquifer. This can be achieved by artificial recharge. Construction of check dams in Anantapur district, India has helped widely to reduce fluoride concentration in groundwater (Bhagavan and Raghu, 2005). Rainfall recharge also called as rainwater harvesting can be adopted using percolation tanks and recharge pits which may prove helpful. Recharge of rainwater after filtration through the existing wells can also be planned to improve the groundwater quality.

\section{Ex-situ-treatment methods}

Numerous ex-situ methods are available for defluoridation of water either at household or community level. Adsorption method involves the passage of water through a contact bed where fluoride is adsorbed on the matrix. Activated charcoal and activated alumina are the widely used adsorbents (Chauhan et al., 2007). Brick, bone char, fly ash, serpentine, red mud, waste mud, rice 
husk, kaolinite, bentonite, charfines, ceramic etc. are some of the other absorbents capable of effectively removing fluoride from groundwater (Chidambaram et al., 2003; Yadav et al., 2006; Chena et al., 2010). The effective removal of fluoride by these absorbents depends on the initial concentration of fluoride, $\mathrm{pH}$, contact time, type of absorbent and its size. A good number of adsorbents are available for fluoride removal from groundwater. Surface adsorption has a major place in defluoridation research and practice because of its general accessibility and lower cost. Alumina-based adsorbents, alumina plus manganese dioxide, iron oxide, calcium minerals, bauxite, laterite ores, clays, soils, zeolite, graphite, carbon nanotubes, resin, and hydroxides are the best sorbents for removal of fluoride that have so far been established. Adsorption by quick lime to remove fluoride is very efficient in comparison to other technologies. Adsorption occurs by replacement of hydroxide ions of $\mathrm{Ca}(\mathrm{OH})_{2}$ by fluoride ions with the formation of CaF2 (Islam, 2007)

$\mathrm{Ca}(\mathrm{OH})_{2}+2 \mathrm{~F}=\mathrm{CaF}_{2}$ (insoluble ppt) $+2 \mathrm{OH}^{-}$

Among the various adsorption techniques, biosorption is an emerging technique for water treatment utilizing abundantly available biomaterials (Bhatnagar, 2011). Since environmental protection is becoming an important global problem, biosorption has become a promising technique for removing fluorides and other toxic ions. Besides this, biosorption are attractive since naturally occurring biomass(es) can be effectively utilized, it offers advantages of low operating cost, minimization of the volume of chemical or biological sludge to be disposed, and high efficiency in dilute effluents. Some effective biosorbents used for fluoride removals are chitosan derivatives (a linear polysaccharides of b-1,4-O-glycosyl-linked glucosamine residue) (Yao and Meng, 2007), algal and fungal biomass, and agricultural wastes such as plant leaves, sawdust, coconut shell, fibers, rice husk, etc (Bhatnagar, 2011).

The unique chemical composition, availability in abundance, and low cost or cost-free ecofriendly options make biomaterials a good choice for removal of fluoride from contaminated waters. In ion exchange process, when water passes through a column containing ion exchange resin, the fluoride ions replace calcium ions in the resin. Once the resin is saturated with fluoride ions, it is backwashed with solution containing chloride such as sodium chloride. The chloride ions thus again replaces the fluoride ions in the resin and is ready for reuse. But the backwash is rich in fluoride and hence care should be taken in disposing this solution. Similarly in precipitation methods, the disposal of sludge with concentrated fluoride is a great problem. Precipitation involves addition of chemicals such as calcium which results in the precipitation of fluoride as fluorite. Aluminium salts are also used for this process. Nalgonda technique which is a wellknown technique uses alum, lime and bleaching powder followed by rapid mixing, flocculation, sedimentation and filtration.

This was developed in India by National Environmental Engineering Research Institute to serve at community and household levels. The resulting sludge from this process contains high amount of aluminium and fluoride, the disposal of which is yet another problem. These above mentioned ex-situ methods are simple and cost effective.

Membrane processes is also an ex-situ technique which includes methods called reverse osmosis and electrodialysis. These are advanced techniques which require high cost input. Both these methods use a semipermeable membrane which removes dissolved solutes from the water. 


\section{Hyperaccumulators of fluoride}

Screening for $\mathrm{F}$ hyperaccumulators can be of great help in phytoremediation of $\mathrm{F}$. The present study was undertaken by Baunthiyal and Mamta (2015) to investigate the potential of eight tree species of semi-arid region viz. Acacia tortilis, Acacia nilotica, Acacia senegal, Prosopis cineraria, Prosopis juliflora, Cassia fistula, Azadirachta indica and Albizzia lebbeck for hyper accumulation of $\mathrm{F}$.

The plants were grown in various concentrations of $\mathrm{F}$ viz. 5, 10, 15, 20 and 50 mg L-1 using hydroponic cultures. Based on the accumulation pattern, three plants viz. A. tortilis, $P$. juliflora and C. fistula were selected for $\mathrm{F}$ uptake and deposition in different organs and their subcellular fractions. Organwise F accumulation studies revealed that roots accumulated maximum $\mathrm{F}$. In general, cytosolic fraction accumulated more $\mathrm{F}$ in comparison to cell wall. Among all plant studied, $P$. juliflora accumulated maximum $\mathrm{F}$, whereas $A$. senegal the minimum. The highest $\mathrm{F}$ accumulation $2222.83 \mu \mathrm{g} \mathrm{g}^{-1}$ was found in $50 \mathrm{mg} \mathrm{L}^{-1} \mathrm{~F}$ treated 10 days old roots of hydroponically grown $P$. juliflora plants. The results suggest potential use of $P$. juliflora in excess $\mathrm{F}$ removal in soil and water bodies.

Apart from all these it is essential to create environmental awareness among public regarding the ill effects of high fluoride. Reduction in the use of fertilisers, especially phosphatic fertilisers is important. It is better to adopt organic farming in places of fluoride threat. In countries with high temperature, it is advisable to reduce evapotranspiration by increasing vegetation cover. This will prevent the deposition of fluoride salts on the unsaturated zone which will subsequently reach the groundwater during rainfall. Other way of combating fluorosis is to modify the dietary intake of the people. Food with more calcium and vitamin $\mathrm{C}$ can prevent fluorosis to a certain extent. Usage of coal for combustion indoors should be avoided and the resultant fly ash obtained from combustion of fossil fuel in industries has to be disposed cautiously.

It is evident from studies by several researchers worldwide that fluoride in groundwater has been a potential problem to human society. The main source of fluoride in groundwater is the rocks which are rich in fluoride. Weathering of these rocks and prolonged residence time leads to high fluoride groundwater. Low calcium, high sodium and high bicarbonate are typical of high fluoride groundwater. Volcanic ash and combustion of coal are the next major source for fluoride.

The other sources for fluoride are infiltration of agricultural runoff containing chemical fertilisers, improper disposal of liquid waste from industries, alumina smelting, cement production and brick firing. Some amount of fluoride is essential for the human body for healthy teeth and bones. But when they are present above the recommended limit of WHO and BIS i.e. $1.5 \mathrm{mg} / \mathrm{l}$ it results in mild dental fluorosis to crippling skeletal fluorosis as the quantity and period of exposure increases.

Dental fluorosis is more prevalent in children than in adults. Skeletal fluorosis occurs when an individual is exposed to fluoride of above $10 \mathrm{mg}$ almost every day over a period of one or two decades. Apart from fluorosis there are also several health disorders due to ingestion of drinking water with high fluoride. To remediate the groundwater with high fluoride, defluorination techniques are adopted. They include adsorption, ion exchange, coagulation and precipitation, reverse osmosis and electrodialysis. Of these, reverse osmosis has 
been considered as the best available technology. Biosorption is still one of the most extensively used methods for defluoridation of drinking water due to it being cost-free or low cost and because of its viability. Onsite treatment includes artificial recharge methods such as rain water harvesting, constructing check dams, percolation ponds, facilitating recharge of rain water through existing wells etc. Adopting a particular method depends on the initial fluoride concentration, source and cost effectiveness in an area.

\section{References}

Apambire, W. B., Boyle, D. R., and Michel, F. A. (1997). Geochemistry, genesis, and health implications of fluoriferous ground waters in the upper regions of Ghana. Environmental Geology, 33(1), 13-24.

Ayoob, S., and Gupta, A. K., (2006) Fluoride in drinking water: a review on the status and stress effects Critical Reviews in Environmental Science and Technology, 36(6), 433-487.

Bailey, J., Chilton, J., Dahi, E., Fawell, J. K., and Fewtrell, L. (2006). Fluoride in drinking-water (World Health Organization Drinking Water). Geneva: World Health Organization.

Baunthiyal, M., and Sharma, V. (2012). Phytoremediation of fluoride contaminated water and soil: a search for fluoride hyperaccumulators. Journal of Agricultural Technology, 8(6), 19651978.

Bhagavan, S. V. B. K., and Raghu, V. (2005). Utility of check dams in dilution of fluoride concentration in ground water and the resultant analysis of blood serum and urine of villagers, Anantapur District, Andhra Pradesh, India. Environmental Geochemistry and Health, 27, 97-108.

Bhatnagar, A., Kumar, E., and Sillanpää, M. (2011). Fluoride removal from water by adsorption-a review. Chemical Engineering Journal, 171(3), 811-840.
CGWB (2006) - Year book of central ground water board for the year 2005-2006

Chae, G. T., Yun, S. T., Mayer, B., Kim, K. H., Kim, S. Y., Kwon, J. S. and Koh, Y. K. (2007) Fluorine geochemistry in bedrock groundwater of South Korea Science of the Total Environment, 385(1), 272-283.

Chauhan, V. S., Dwivedi, P. K., and Iyengar, L. (2007). Investigations on activated alumina based domestic defluoridation units. Journal of Hazardous Materials, B139, 103-107.

Chena, N., Zhang, Z., Feng, C., Li, M., Zhu, D., Chen, R., and Sugiura, N. (2010). An excellent fluoride sorption behavior of ceramic adsorbent. Journal of Hazardous Materials, 183, 460-465.

Chhabra R, Singh A, Abrol IP (1980) Fluorine in sodic soils. Soil Sci Soc Am J 44:3336

Chidambaram, S., Ramanathan, A. L., and Vasudevan, S. (2003). Fluoride removal studies in water using natural materials. Water SA, 29(3), 339-344.

Cronin, S. J., Manoharan, V., Hedley, M. J., and Loganathan, P., (2000) Fluoride: A review of its fate, bioavailability, and risks of fluorosis in grazed- pasture systems in New Zealand New Zealand Journal of Agricultural Research, 43(3), 295-321.

Dissanayake, C. B. (1991). The fluoride problem in the ground water of Sri Lanka - environmental management and health. International Journal of Environmental Studies, 38(2-3), 137-155.

Fawell, J., Bailey, K., Chilton, J., Dahi, E., Fewtrell, L., and Magara, Y. (2013). Fluoride in drinking-water. Water Intelligence Online, 12, 9781780405803.

Fuge R (1988) Sources of halogens in the environment, influences on human and animal health. Environ Geochem Health 10(20):51-61

Fuge, R., and Andrews, M. J. (1988). Fluorine in the UK environment. Environmental geochemistry and health, 10(3-4), 96-104.

Geebelen, W., Bijnens, O., Claeys, N., Adriaenssens, E., Makkonen, S., Ruttens, 
A., and Vangronsveld, J. (2006). Transplanted lichens as biomonitors for atmospheric fluoride pollution near two fluoride point sources in Flanders (Belgium). Belgian Journal of Botany, 138(2), 141-151.

Gehlhausen, J. M., and Carnahan, J. W. (1989). Determination of aqueous fluoride with a helium microwave-induced plasma and flow injection analysis. Analytical chemistry, 61(7), 674-677.

Guo Q, Wang Y, Ma T, Ma R (2007) Geochemical processes controlling the elevated fluoride concentrations in groundwaters of the Taiyuan Basin, Northern China. J Geochem Explor 93:112

Gupta, S., and Banerjee, S. (2011). Fluoride accumulation in crops and vegetables and dietary intake in a fluoride-endemic area of West Bengal. Fluoride, 44(3), 153.

Gutsche, B., Kleinoeder, H., and Herrmann, R. (1975). Device for trace analysis for fluorine in reaction tubes by atomicabsorption spectroscopy. Analyst, 100 (1188), 192-197.J.M. Gehlhausen, J.W.

Haidouti C (1991) Fluoride distribution in soils in the vicinity of a point emission source in Greece. Geoderma 49:129-138

Handa, B. K. (1975). Geochemistry and genesis of Fluoride- Containing ground waters in India. Ground water, 13(3), 275-281.

Hem, J. D. (1985). Study and interpretation of the chemical characteristics of natural water (Vol. 2254). Department of the Interior, US Geological Survey.

Hyndman DW (1985) Petrology of igneous rocks, 2nd edn. McGraw-Hill, New York, NY.

Islam, M., and Patel, R. K. (2007). Evaluation of removal efficiency of fluoride from aqueous solution using quick lime. Journal of Hazardous Materials, 143(1), 303-310.

Jha, S. K., Mishra, V. K., Sharma, D. K., and Damodaran, T. (2011) Fluoride in the environment and its metabolism in humans In Reviews of Environmental
Contamination and Toxicology Volume 211 (pp. 121-142) Springer New York.

Jha, S. K., Nayak, A. K., and Sharma, Y. K. (2009) Fluoride toxicity effects in onion (Allium cepa L.) grown in contaminated soils Chemosphere, 76(3), 353-356.

Jones, P. (1992). Development of a highsensitivity ion chromatography method for the determination of trace fluoride in water utilizing the formation of the $\mathrm{AlF}$ $2+$ species. Analytica chimica acta, 258(1), 123-127.

Joshi, S., Hlaing, T., Whitford, G. M., and Compston, J. E. (2011). Skeletal fluorosis due to excessive tea and toothpaste consumption. Osteoporosis international, 22(9), 2557-2560.

Keller EA (1979) Environmental geology. Charles and Merril, Columbus.

Kim K, Jeong GY (2005) Factors influencing natural occurrence of fluoride-rich ground waters: a case study in the southeastern part of the Korean Peninsula. Chemosphere 58:1399-1408.

Kirk-Othmer (1980) Encyclopedia of chemical technology, vol. 10, 3rd edn. Wiley, New York.

Larsen, S., and Widdowson, A. E. (1971). Soil fluorine. Journal of soil science, 22(2), 210-221.

Leon Gonzalez, M. E., Santos-Delgado, M. J., and Polo-Diez, L. M. (1989). Flowinjection spectrophotometric determination of fluoride based on alizarin fluorine blue in the presence of sodium dodecyl sulphate. Analytica Chimica Acta, 219, 329-333.

Liteplo, R., R. Gomes, P. Howe, H. Malcolm, Fluorides (World Health Organization, Geneva, 2002).

McLaughlin MJ, Tiller KG, Naidu R, Stevens DP (1996) Review: the behavior and environmental impact of contaminants in fertilisers. Aust J Soil Res 34:1-54.

Omueti JAI, Jones RL (1977) Fluoride adsorption by Illinois soil. J Soil Sci 28:564-572. 
Pickering WF (1985) The mobility of soluble fluoride in soils. Environ Pollut Ser B 9(44):281-308.

Reimann C, Decaritat P (eds) (1998) In: Chemical elements in environment. Fact sheets for the geochemist and environmental scientist. Springer, New York, NY.

Ruan, J., Ma, L., Shi, Y., and Han, W. (2003). Uptake of fluoride by tea plant (Camellia sinensis L) and the impact of aluminium. Journal of the Science of Food and Agriculture, 83(13), 1342-1348.

Saxena VK, Ahmed S (2003) Inferring the chemical parameters for the dissolution of fluoride in ground water. Environ Geol 43(6):731-736.

Saxena VS, Ahmed SA (2001) Dissolution of fluoride in groundwater: a water-rock interaction study. Environ Geol 40:10841087. doi:10.1007/s002540100290.

Skjelkvåle, B. L. (1994). Factors influencing fluoride concentrations in Norwegian lakes. Water, Air, and Soil pollution, 77(1-2), 151-167.

Susheela AK (2003) Treatise on fluorosis, 2nd edn. Fluorosis Research and Rural Development.

Tang, Q., Du, J., Ma, H., Jiang, S., and Zhou, X. (2008). Fluoride and Children's Intelligence: A Meta-analysis. Biol Trace Elem Res, 126, 115-120.

Teotia SPS, Teotia M (1994) Dental caries: a disorder of high fluoride and low dietary calcium interactions (30 years of personal research). Fluoride 27:59-66.

Tripathi, N., Bajpai, S., and Tripathi, M. (2009). Genotoxic alterations induced by fluoride in Asian catfish, Clarias batrachus (Linn.). Fluoride, 42(4), 292-296.

Trivedi MH, Verma RJ, Chinoy NJ et al., (2007) Effect of high fluoride water on intelligence of school children in India. Fluoride, 40, 178-183.

Wenzel WW, Blum WEH (1992) Fluorine speciation and mobility in contaminated soils. Soil Sci 153(5):357-364.

World Health Organization (1992) Guidelines for drinking-water quality: recommendations (Vol. 1) World Health Organization.

World Health Organization (2004) Guidelines for drinking-water quality: recommendations (Vol. 1) World Health Organization.

Yadav, A. K., Kaushik, C. P., Haritash, A. K., Kansal, A., and Rani, N. (2006). Defluoridation of groundwater using brick powder as an adsorbent. Journal of Hazardous Materials, B128, 289-293.

Yao, R., Meng, F., Zhang, L., Ma, D., and Wang, M. (2009). Defluoridation of water using neodymium-modified chitosan. Journal of hazardous materials, 165(1), 454-460.

\section{How to cite this article:}

Neelam Yadav, Khushboo Rani, S.S. Yadav, D.K. Yadav, V.K. Yadav and Nagesh Yadav. 2018. Soil and Water Pollution with Fluoride, Geochemistry, Food Safety Issues and Reclamation-A Review. Int.J.Curr.Microbiol.App.Sci. 7(05): 1147-1162. doi: https://doi.org/10.20546/ijcmas.2018.705.140 